\title{
Estimating the opportunity costs of environmental conservation in the Feijão River watershed (São Carlos-SP, Brazil)
}

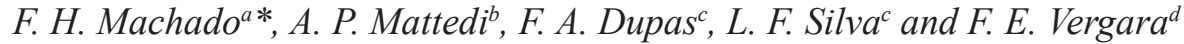 \\ aUniversidade Federal de Itajubá - UNIFEI, Av. BPS 1303, CEP 37500-000, Itajubá, MG, Brazil \\ 'Institute of Compuet ter Sciences and Mathematics, Universidade Federal de Itajubá - UNIFEI, \\ Av. BPS 1303, Pinheirinho, CEP 37500-000, Itajubá, MG, Brazil \\ 'Institute of Natural Resources, Universidade Federal de Itajubá - UNIFEI, Av. BPS 1303, Pinheirinho, \\ CEP 37500-000, Itajubá, MG, Brazil \\ ${ }^{d}$ Universidade Federal de Tocantins - UFT, ALC NO 14 NS 15, Centro, CEP 77010-090, Palmas, TO, Brazil \\ *e-mail: fernandomtb@hotmail.com
}

Received: May 12, 2014 - Accepted: October 22, 2014 - Distributed: February 29, 2016

(With 1 figure)

\begin{abstract}
The objective of this study was to infer the opportunity cost of land use of the Feijão River watershed (São Carlos-SP, Brazil), in order to estimate the financial resources necessary to compensate landowners willing to convert their production areas into areas of environmental preservation. Net values were estimated by calculating the Annual Value and the Net Present Value of each activity. The area used for agricultural production was estimated using the Land Cover Map of the watershed. The study involved four production areas: forestry, livestock, sugarcane and orange, accounting for $66 \%$ of the watershed area of 22,300 hectares. Considering a scenario of total consent from landowners, the 2011 net annual values were estimated at R\$ 13.4 million: R 2.2 million (eucalyptus), R \$ 1.9 million (livestock), R\$ 1.1 million (sugarcane) and R\$ 8.2 million (orange). This amount would be used as payment for ecosystem services.
\end{abstract}

Keywords: opportunity cost, watershed, ecosystem services, payment for ecosystem services (pes).

\section{Estimativa dos custos de oportunidade para a conservação ambiental na bacia hidrográfica do Ribeirão do Feijão (São Carlos - SP, Brazil)}

\begin{abstract}
Resumo
O objetivo deste estudo foi inferir o custo de oportunidade do uso do solo da bacia hidrográfica do manancial do Ribeirão do Feijão, São Carlos - SP, a fim de estimar o valor necessário para ressarcir os proprietários de terras dispostos a converter suas áreas produtivas para áreas de proteção ambiental. Os valores líquidos foram estimados pelo cálculo do Valor Anual e o Valor Presente Líquido de cada tipo de atividade. A área ocupada foi estimada utilizando o mapa de cobertura de solo. Foram analisadas quatro áreas produtivas, das quais: reflorestamento, pecuária, cana-de-açúcar e laranja, que juntas representam $66 \%$ da área total da bacia, que totaliza $223 \mathrm{~km}^{2}$. Os valores líquidos anuais, referentes ao ano de 2011 e considerando um cenário de total adesão dos proprietários, foram estimados em R $\$ 13,4$ milhões: R\$ 2,2 milhões (eucalipto), R\$ 1,9 milhão (pecuária), R\$ 1,1 milhão (cana-de-açúcar) e R\$ 8,2 milhões (laranja). Este montante seria o valor necessário estimado para fins de ressarcimento pela prestação dos serviços ambientais da bacia.
\end{abstract}

Palavras-chave: custo de oportunidade, bacia hidrográfica, serviços ecossistêmicos, pagamento por serviços ecossistêmicos (pse).

\section{Introduction}

In 2013 the agriculture and livestock sector responded for about $23 \%$ of the Brazilian Gross Domestic Product - GDP (CEPEA, 2014) and accounted for $41 \%$ of the exportations (CONAB, 2014). According to the last Agriculture and Livestock census by the Brazilian Institute for Geography and Statistics - IBGE, the agriculture and livestock production used around $42 \%$ (355 million hectare) of the Brazilian territory in 2006 (IBGE, 2007). Due to the country's rich flora and fauna and extensive land area, Brazil is among a few countries able to produce food, preserve biodiversity and keep adequate ecosystem services. However, consideration should be given to the fact that agriculture can only exist in balanced ecosystems able to provide for ecosystem services. Therefore, a well-preserved nature is the most precious asset of agriculture (Martinelli and Filoso, 2009). 
The conversion of native vegetation into agriculture and pasture areas drastically reduces biodiversity of affected biomes (Galindo-Leal and Câmara, 2003; Watanabe et al., 2012). Martinelli et al. (2010) report that the development of the Brazilian agriculture and livestock activities are associated with massive deforestation. An aspect disregarded in this process is the replacement of native vegetation by agriculture and livestock activities, resulting in great loss of the ecosystem services.

Pollution considerably increases the costs for treatment of the public water supply, whereas protected areas with good quality watersheds demand less investment. According to Tundisi and Matsumura-Tundisi (2010), treatment costs may be, at most, between R\$2.00 and R\$ 3.00 per $1,000 \mathrm{~m}^{3}$ of treated water in these environments, however, due to deforestation and watershed degradation, these costs increase to $\mathrm{R} \$ 250.00$ or $\mathrm{R} \$ 300.00$ per $1,000 \mathrm{~m}^{3}$. Approximately $55 \%$ of the variations in water treatment costs are related to the percentage of forest cover in the watershed and for each $10 \%$ increase in the forest cover there is a $20 \%$ reduction in water treatment costs up to approximately $60 \%$ of coverage (Ernst, 2004).

The ecosystem services provided by watersheds, specifically the hydrological services, can be described in four major categories: filtration of water, water regime regulation, erosion control and sediment and preservation of habitat (Postel and Thompson, 2005 and Periotto and Tundisi, 2013). Therefore, watersheds with natural characteristics are essential for the correct functioning of the system and the evaluation of these services contribute substantially to sustainable management of natural capital (Frelichová et al., 2014).

Studies performed by Dupas (2001), Cunha et al. (2011), Costa et al. (2012, 2013), Machado and Dupas (2013) and Machado et al. (2014) depict intensive land use due to agricultural activities and population growth resulting in adverse impacts to the land cover in São Carlos - SP, most specifically in the Feijão River watershed. Such impacts are caused mainly due to sugarcane, orange and livestock activities in highly fragile environmental areas regarded as aquifer recharge areas (Tundisi et al., 2008; Zuquette et al., 2009). Disordered development as a result of lack of planning generates high costs to the city administration and, as consequence, to the population (Sperandelli et al., 2013).

Based on the above, the Feijão River watershed is regarded as an important and strategic environmental asset of São Carlos, with its preservation and/or conservation being essential as a public water supply watershed. Therefore, the purpose of this study was to estimate the opportunity cost of agriculture and livestock production in areas within the Feijão River watershed, with a view to offer financial compensation to landowners willing to convert their land into areas of environmental preservation.

\section{Methods and Material}

\subsection{Study area}

The Feijão River, a public water supply watershed in the city of São Carlos, is located in the southeast region of the country, $230 \mathrm{~km}$ northwest of São Paulo, with mild climate, uneven terrain, annual average temperature of $19.5^{\circ} \mathrm{C}$ and average altitudes ranging between 800 and 1000 meters, with cerrado (tropical savanna) being the predominant biome (Dupas et al., 2006). According to IBGE (2014) data, the city has a population of 228,556 inhabitants (about 20,000 are floating population), 1,141 $\mathrm{km}^{2}$ of land and a population density of 201 inhabitants per $\mathrm{km}^{2}$ in 2013. The population is predominantly urban and the GDP was $R \$ 5.526$ million ( $\mathrm{R} \$ 24,678.10$ per capita) in 2011 (SEADE, 2014).

The Feijão River is a sub-watershed of the Water Resources Management Unit $n^{\circ} 13$ (Tietê/Jacaré) of São Paulo state, situated in the center of the state with 34 cities in the countryside (Tundisi et al., 2008). Located between $22^{\circ}$ and $22^{\circ} 10^{\prime}$ parallels of south latitude and $47^{\circ} 45^{\prime}$ and $47^{\circ} 50^{\prime}$ meridians of west longitude, its water spring is in Cuscuzeiro Hill (Analândia-SP), in Bauru's sandstone-basalt interface (SAAE, 1995).

The Feijão River watershed is São Carlos' primary raw water supply source (Rodríguez, 2001; SAAE, 1989), accounting for $27 \%$ of the total volume of surface water collected for public supply in 2009. The Feijão River drains the Itirapina plateau (where part of the tributary springs are located), a depressed formation among the Itaqueri and Santana do Sul Hills with Cuscuzeiro and São Carlos Hills to the north. It runs NE-SW and ENE-WSW upon sandstones along the Botucatu formation in its mid and long courses; in its lowest part it runs over diabasic terrain of basaltic origin between layers of Botucatu (SAAE, 1995). The perimeter of the watershed is $68.75 \mathrm{~km}$; average declivity of $2.73 \%$; maximum altitude of 1,020 meters; average altitude of 870 meters; minimum altitude of 720 meters; and drainage area of $223 \mathrm{~km}^{2}$ (SAAE, 1989).

Figure 1 shows the land cover map and the drainage system of the Feijão River. The cartographic elements adopted for the map elaboration follow guidelines from the Brazilian Geodesic System, making use of the planimetric datum of Alegre Stream, which uses the Hayford ellipsoid, with projection in degrees, minutes and seconds in relation to the 23 Time Zone and the altimetry data of Imbituba Marigraph. The map elaboration was performed through supervised ranking (maximum-likelihood estimation) using an Alos satellite image dated November 12th, 2006, with $10 \mathrm{~m}$ of spatial resolution (Cunha, 2012). In this figure is shown the extent of pasture areas, sugarcane, orange and forestry/reforestation activities in the Feijão River watershed. It is also observed the urban sprawl of Sao Carlos inside the perimeter of the watershed, the result of a population growth of $226 \%$ and a $310 \%$ increase of impervious surface between the years 1962 to 2006 (Costa et al., 2013). 


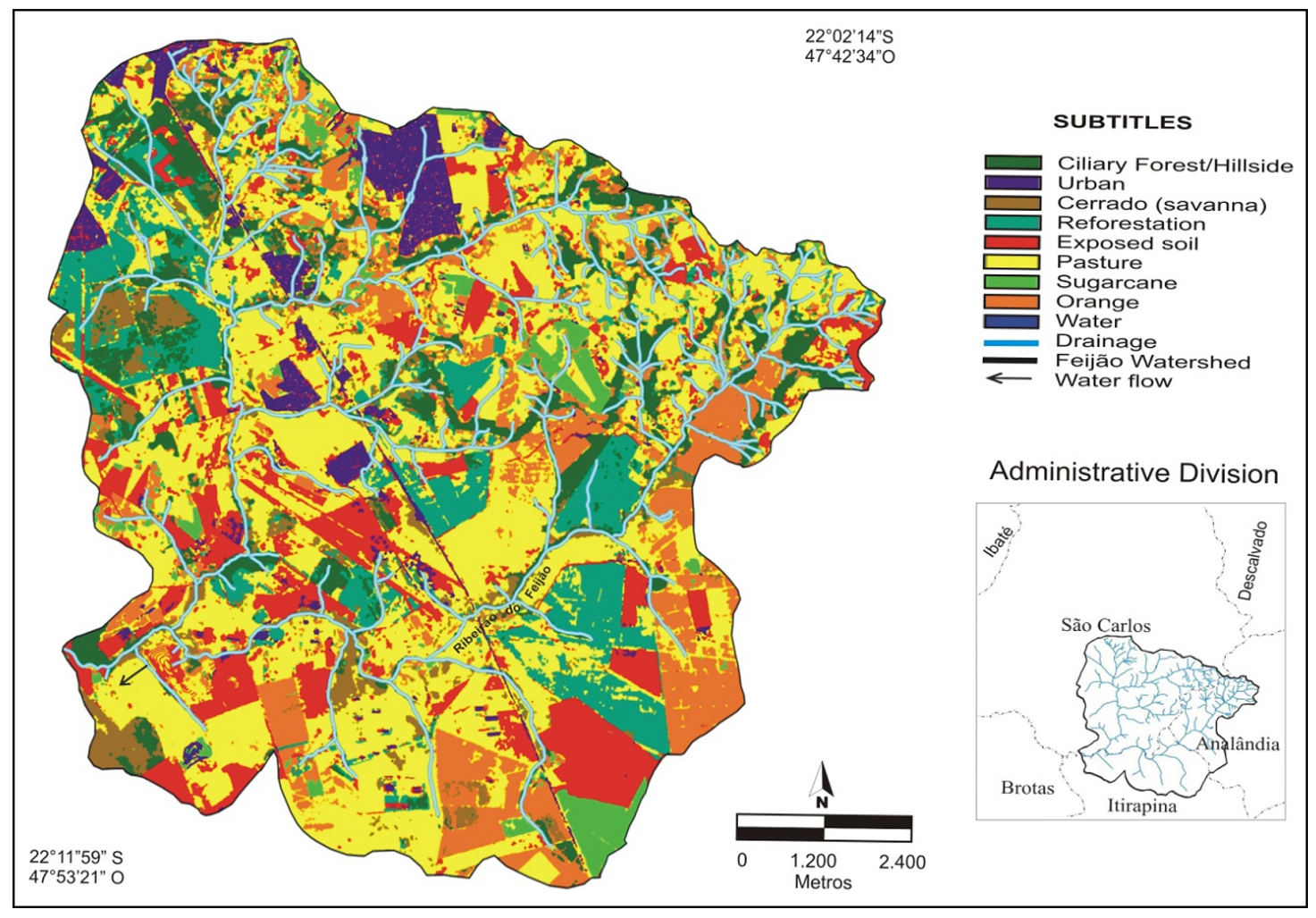

Figure 1. Land cover map of the Feijão River watershed made from the ALOS satellite imagery of November 2006. Source: Adapted from Cunha (2012).

Table 1 shows the distribution of different covers in the watershed and their respective percentages. The most predominant is pasture, accounting for $38 \%$ of the area, followed by orange activities (14\%).

\subsection{Economic analysis}

Studies on the economic valuation of the environmental impacts caused by anthropic activities over natural resources have been performed incorporating economic analysis in the environmental dimension. Such valuation are comprised a set of methodologies to estimate values for the environmental assets and for the goods and services they generate (Machado and Dupas, 2013).

Based on production costs and on the financial return for the agriculture and livestock activities developed in the watershed, the net profit was estimated for each type of culture. The purpose was to identify the financial investment necessary to indemnify rural landowners willing to convert agricultural areas into areas of environmental protection and thus improve the offer of water with better quality and higher quantity.

The proposal is based on opportunity cost, which refers to the difference between the income derived from the land before the Payment for Ecosystem Services - PES and after the adoption of the PES and their respective conservationists measures (Wünscher et al., 2008). The opportunity costs of conservation are defined by the lost opportunities that
Table 1. Distribution of land cover in the Feijão River watershed in the year 2006 .

\begin{tabular}{lcc}
\hline \multicolumn{1}{c}{ Cover classes } & $\begin{array}{c}\text { Area } \\
\text { (ha) }\end{array}$ & $\begin{array}{c}\text { Area } \\
\text { (\%) }\end{array}$ \\
\hline Ciliary forest/Hillside & 2,358 & 10.58 \\
Urban & 1,084 & 4.84 \\
Cerrado (savanna) & 1,293 & 5.78 \\
Reforestation & 2,281 & 10.22 \\
Exposed soil & 2,861 & 12.83 \\
Pasture & 8,647 & 38.79 \\
Sugarcane & 681 & 3.05 \\
Orange & 3,085 & 13.86 \\
Water & 13 & 0.04 \\
Total & $\mathbf{2 2 , 3 0 2}$ & $\mathbf{1 0 0}$ \\
\hline Source: Adapt
\end{tabular}

Source: Adapted from Cunha (2012).

occur in the process of using land for economic purposes (Adams et al., 2010).

With this proposal, producers in the Feijão River watershed would give up using the land for economic purposes to receive financial compensation to protect the area at the amount of the net profit of the current land cover. It is worth mentioning that the intention was to identify the opportunity cost involved in ceasing agriculture and livestock production. Overhead costs, such as social costs 
(unemployment), conversion costs, and tax collection, among others, were not considered, but require further studies.

The market price of the lands subject to this study were not considered either, once they may be converted into monetary units when sold or the owners may be indemnified in case of expropriation. Furthermore, indirect revenue from the protection of the watershed, such as costs reduction for treating the public water supply, among others, was also not accounted for.

To create the proposal, a land cover map and its respective areas were used as a source of data (Figure 1 and Table 1). A fieldwork study was performed in the watershed in March 2010 aimed at analyzing the area and checking if the covers seen in the map were consistent with reality on the ground.

Productive areas defined in this economic analysis were: reforestation (eucalyptus cultivation), pasture (beef cattle), sugarcane and orange. The exposed soil, in spite of representing a possible area for agriculture and livestock activities, was not considered in this analysis, as it may represent degraded areas not used for economic purposes, as well as resting areas for culture or pasture rotation. Therefore, we opted for a more conservative estimation, which, somehow, can underestimate the final estimation.

\subsubsection{Methods of economic analysis}

The Uniform Annual Value - AV is a method to analyze a project's feasibility with different lifespans, such as for this study. The AV represents an equivalent uniform annual value of all estimated, paid and received amounts during the life-cycle of a project (Blank and Tarquin, 2008). This method divides the project's current net value by equal values of $n$ throughout the project's lifespan, although calculated from the same focal date. According to Neves (2005), the AV is expressed by Equation 1:

$$
A V=N P V * \frac{(1+i)^{n} * i}{(1+i)^{n}-1}
$$

Where:

$\mathrm{AV}=$ Annual Value

NPV - Net Present Value $i=$ Attractive rate of the period $n=$ Total number of time periods

In order to calculate the $\mathrm{AV}$, it is necessary to calculate the Net Present Value of the project. The method of Net Present Value (NPV) determines investment feasibility by calculating the positive difference between revenues and costs, updated to the present time, by a minimum attractive rate (Dossa et al., 2000). Despite the change risk analysis had not been considered in its variables, NPV is one of the most commonly used methods to analyze investments, as it complies with a set of important properties, among which are: cash flow, money value over time, all cash flows of the period, only one result, and no scale problems (Ross et al., 2002). According to Ross et al. (2002), the NPV is calculated by Equation 2:

$N P V=\sum_{j=0}^{n} \frac{R_{j}-C_{j}}{(1+i)^{n}}$

Where:

$R_{j}=$ Revenue of the period $j$

$C_{j}^{j}=$ Cost of the period $j$

$i=$ Interest rate $(\%$ per year $)$

$j=$ Period of revenue or cost (years)

$n=$ Maximum number of periods (years)

According to the NPV, if the present value of the sum of expenses and revenues is positive, the project is viable; otherwise, the project is deemed economically unviable. An important variable is the choice of interest rate. In this study, the rate used to calculate the NPV for all activities analyzed was $6.75 \%$ per year. This interest rate is the same used in governmental programs for rural credit, as described in the 2010-2011 Agricultural and Livestock Plan of the Ministry of Agriculture, Livestock and Food Supply (Brasil, 2009).

\subsubsection{Data sources}

Due to lack of data, especially for production costs, and costs and revenues of agricultural products from different datasets, it was necessary to use different periods as well as different Brazilian States. Table 2 shows the respective reference years of the data used in this study.

Subsequently, the values (Table 2) were adjusted for the year 2011 according to the monetary updating of the respective periods (i.e., values of costs and revenues of years prior to 2011 were updated following annual monetary updating as per the National Broad Consumer Price Index - IPCA (IBRE, 2011). Table 3 shows the 2004 to 2010 annual inflation rates used to update the values and to estimate the inflation of the referred period.

\subsubsection{Comparison between producers' profits and people's willingness to pay}

The outcome of the economic analysis of land use was compared with the values of Willingness to Pay - WTP of the population of São Carlos to protect the Feijão river watershed in order to determine a representative WTP figure. The WTP was estimated by Machado and Dupas (2013) utilizing the Contingent Valuation Method - CVM, with data collected through personal interviews using questionnaires conducted at the interviewees' homes.

Table 2. Years of costs and revenues of agriculture and livestock activities.

\begin{tabular}{lll}
\hline \multicolumn{1}{c}{ Activity } & Year & \multicolumn{1}{c}{ Source } \\
\hline Eucalyptus & 2007 & Anuário da Agricultura Brasileira - Agrianual (2008) and Galo (2008) \\
Beef cattle & 2009 & Anuário da Pecuária Brasileira - Anualpec (2010) \\
Sugarcane & 2011 & Federação da Agricultura e Pecuária do Estado de Goiás - FAEG (2011) \\
Orange & 2004 & Ghilardi et al. (2004) e Instituto de Economia Agrícola de São Paulo (IEA, 2010) \\
\hline
\end{tabular}


In October 2010, 280 questionnaires were responded to by probabilistic sample of the population. The interview was preferably carried out with the head of the household or, alternatively, with a person in the household that was 18 or over. The referendum model and bidding-games were used as the elicitation technique. The structure of the questionnaire (addressing socio-economic characteristics and questions concerning the environmental perception of the interviewee) consisted of dichotomous choices and multiple choice questions, all conducted by the interviewer.

\section{Results and Discussion}

\subsection{Estimation of net profit produced in the watershed}

Below are the net profit estimated values produced for each type of agriculture and livestock activity in the land cover map of the Feijão River watershed, calculated from Equations 1 and 2. Table 4 shows the results obtained for the production of orange, sugarcane, eucalyptus (reforestation) and beef cattle (pasture).

Table 3. Annual inflation rate IPCA/IBGE.

\begin{tabular}{cc}
\hline Year & IPCA (\% per year) \\
\hline 2004 & 6.6 \\
2005 & 6.87 \\
2006 & 4.18 \\
2007 & 3.64 \\
2008 & 5.9 \\
2009 & 4.31 \\
2010 & 5.91 \\
\hline
\end{tabular}

Source: IBRE (2011).
The net profit from the area allocated to reforestation (in this study, eucalyptus plantation - as verified in fieldwork) was estimated based on data collected from the Agriculture in Brazil Yearbook (Agrianual, 2008; Galo, 2008). An eighteen-year lifespan life was estimated, with three cut periods for the region of Minas Gerais State, three cuts in the period (year $6,12,18$ ), density of 1,600 tree/ha and spacing of $3 \times 2$ (Agrianual, 2008). All data related to the 18-year period making up the eucalyptus productive cycle are from 2007. Therefore, values were updated to 2011 based on accumulated inflation rate from 2007 to 2010 .

The total estimated net values for the eucalyptus plantation in one cycle only were around $\mathrm{R} \$ 9,751$ per hectare or R\$ 952 per ha/year. Extrapolating this value to the eucalyptus farming area in the watershed (2,281 ha), we have a value close to $\mathrm{R} \$ 2.2$ million per year.

Revenues and production costs provided by the Agriculture and Livestock Federation of the State of Goiás - FAEG (2011) were used to calculate the values of a five-year sugarcane cycle. The first cut is referred to as "cane plant" and, from the 2 nd to the 5 th, "ratoon cane". Based on these results, we can estimate that for each hectare the annual net revenue is $\mathrm{R} \$ 1,581$. Extrapolating this result to the current 681 hectares of sugarcane plantation in the watershed, we have annual revenue of about $\mathrm{R} \$ 1.1$ million.

The net revenue evaluation for the orange culture was performed based on production costs and revenues of industries in the south of the state of São Paulo. According to Ghilardi et al. (2004), in a 19-year life cycle of orange orchards, four years are unproductive (growth period). For our study we considered a productive orchard with 300 plants per hectare, producing 600 boxes of $40.8 \mathrm{~kg}$ (average production of a 7 to 9 -year orchard) at the cost

Table 4. Opportunity cost from agriculture and livestock activities analyzed (adjusted to the year 2011).

\begin{tabular}{|c|c|c|c|c|c|}
\hline Description & Unit & Eucalyptus & Sugarcane & Orange & Cattle \\
\hline Used area (Figure 1) & ha & 2,281 & 681 & 3,085 & 8,647 \\
\hline Length of cycle (full cycle) & years & 18 & 5 & 19 & 2.75 \\
\hline Revenue considering the full cycle & $\mathrm{R} \$ /$ ha/year & 28,700 & 24,595 & 73,620 & - \\
\hline Cost considering the full cycle & $\mathrm{R} \$ /$ ha/year & 20,658 & 18,070 & 54,132 & - \\
\hline $\begin{array}{l}\text { Result considering the full cycle } \\
\text { (revenue - cost) })^{1,2}\end{array}$ & $\mathrm{R} \$ /$ ha/year & 8,042 & 6,526 & 19,488 & 202 \\
\hline $\begin{array}{l}\text { Updated value per accumulated inflation rate of } \\
\text { the last } 7 \text { years }(2004-2010)\end{array}$ & $\mathrm{R} \$$ & - & - & 28,044 & - \\
\hline $\begin{array}{l}\text { Updated value as per accumulated inflation rate } \\
\text { of the last } 4 \text { years }(2007-2010)\end{array}$ & $\mathrm{R} \$$ & 9,751 & - & - & - \\
\hline $\begin{array}{l}\text { Updated value as per accumulated inflation rate } \\
\text { of the last } 2 \text { years }(2009-2010)\end{array}$ & $\mathrm{R} \$$ & - & - & - & 223 \\
\hline $\begin{array}{l}\text { Correction factor by the agriculture and livestock } \\
\text { sector finance rate }{ }^{3} \\
(6.75 \% \text { - rate used to calculate the NPV) }\end{array}$ & - & 10.2 & 4.4 & 10.5 & - \\
\hline Annual value in 1 ha & $\mathrm{R} \$$ & 952 & 1,581 & 2,663 & $223^{3}$ \\
\hline Annual value per total used area & $\mathrm{R} \$$ (million) & 2,171 & $\mathbf{1 , 0 7 7}$ & 8,215 & 1,928 \\
\hline $\begin{array}{l}\text { Total annual value } \\
\text { (orange }+ \text { sugarcane }+ \text { eucalyptus }+ \text { cattle) }\end{array}$ & $\mathrm{R} \$$ (million) & 13,391 & & & \\
\hline
\end{tabular}

${ }^{1}$ Forecasted values disregarding monetary update of the execution time (except sugarcane - date of 2011). ${ }^{2,3}$ Estimated by Anualpec (2010). 
of R $\$ 6.01$ per box in May 2004. The producer received $\mathrm{R} \$ 8.18$ per box in the referred month (online databank of the Institute of Agricultural Economics - IEA, 2010). The data was updated to take into account the accumulated inflation of the last six years (2004-2010). The annual net profit per hectare was around $\mathrm{R} \$ 2,663$. Extrapolating this result to the orange plantation area in the watershed ( $2,281 \mathrm{ha})$, the estimated net profit was $\mathrm{R} \$ 8.2$ million/year.

In terms of pasture, we considered the area for the growth, reproduction and fattening of extensive beef cattle - the main activity observed in the fieldwork. As the data was from 2009, the values had to be updated to 2011. The estimation resulted in a net profit for beef cattle of around $\mathrm{R} \$ 223$ per ha/year, which totals to R $\$ 1.9$ million/year for an area of 8,647 hectares.

The total annual net profit of the four studied activities in the watershed (accounting for $66 \%$ of its total area) is in the order of R $\$ 13.4$ million. Of the four productive activities, the most profitable per hectare/year is orange $(\mathrm{R} \$ 2,663)$, followed by sugarcane $(\mathrm{R} \$ 1,581)$, eucalyptus $(\mathrm{R} \$ 952)$ and beef cattle $(\mathrm{R} \$ 223)$.

\subsection{Producers' profits and people's willingness to pay}

The study carried out by Machado and Dupas (2013) showed that the WTP of São Carlos inhabitants for the environmental protection of the Feijão River watershed is $\mathrm{R} \$ 3.1 /$ person/month. Extrapolating this value to the city's population, Machado and Dupas (2013) estimated that an amount of R $\$ 8.2$ million/year that could be allocated to the environmental protection of the watershed.

Comparing the estimated values with the four productive activities in the watershed with the amount obtained with the population's WTP, we observe that the later represents approximately $60 \%$ of the amount needed to cover the total production of the agriculture and livestock activities analyzed in this study. Considering the amount that could be collected annually for the environmental protection of the watershed ( $\mathrm{R} \$ 8.2$ million), this value would be equivalent to $\mathrm{R} \$ 558 \mathrm{ha}^{-1}$.year-1 of the productive area covered in this study or R $\$ 368 \mathrm{ha} /$ year of the watershed's total area.

This financial resource, once collected, may be used for the protection of the watershed in different ways, such as: partial financial compensation to cease productive activities that impact the environment negatively, incentive to implement organic agricultural practices, and payment for ecosystem services to rural producers who allocate areas to environmental protection.

Thus, this would encourage producers to change their production practices and would, possibly, improve their chances of making profits with more sustainable means. The replacement of unsustainable practices to organic agriculture and livestock could result in higher financial profits in the future.

In this process, priority areas should still be defined for implementation of the proposal. Technical issues must be taken into consideration, such as greater attention to the anthropogenic pressures close to water courses or areas of recharge groundwater. The halting of activities located in places that can bring some risk or damage to water resources should also be considered. It should also be highlighted that different activities have different degrees of impact on the water resources. Thus, in the implementation of this proposal, criteria must be created to establish the anthropogenic pressures and their relative impacts, give priority to stopping the most harmful activities.

In this context, we highlight that this study may be used as a management tool, serving as a guideline in decision-making processes concerning policies for the protection of watersheds in São Carlos as well as in the other cities comprising the watershed. For this case study, the payment for ecosystem services, most specifically for water production, shall be regarded as a strategy to preserve and assure water supply to urban areas. This way, the benefits will be for those using and those preserving the watershed through the recovery of degraded areas.

How costs will be shared among urban environments in need of water is a current issue that foresees the compensation of landowners who profit from agriculture and livestock activities. Obviously, to make this proposal effective, negotiations are essential with landowners. From an amount of $223 \mathrm{~km}^{2}$, only $120.3 \mathrm{~km}^{2}$ are in São Carlos; however, the city is the most urbanized/waterproof with $5.9 \%$ of the area, which, according to Tundisi et al. (2007), has the greatest pollution indexes as a result of residual effluents disposal.

\section{Conclusions}

According to Hupffer et al. (2011, p. 102), "[...] the adoption of fiscal, tax and credit incentives has gained recognition in the environmental area, mainly from the concept of the protector-receiver principle." Based on this assumption, this study was aimed at establishing the opportunity cost required to indemnify rural producers willing to cease their livestock activities to preserve the Feijão River watershed by turning it into an environmental protection area, as well as comparing if the WTP of the city of São Carlos estimated by Machado and Dupas (2013) would be enough to cover the cost. However, this result shows that the population is aware of the importance of preserving the watershed, and that alternatives must be found for the financial deficiency.

If the objective is to immediately start replacing productive processes, a possible approach could be to get resources from alternative sources in the legislation by mechanisms of fiscal exemption from the Corporate Fiscal Responsibility - Normative Instruction nº. 87/1996 (Brasil, 1996). It should be considered that there is a large financial savings in the water treatment process due to preservation of a river basin (Tundisi and Matsumura-Tundisi, 2010). The São Carlos population, main beneficiary of this proposal, also proved to be willing to pay any amount for the preservation of water resources in the Feijão River watershed. Thus, this financial resource could be used to compensate producers who preserve their land. Other sources 
of financial resources in Brazil are described by Whately and Hercowitz (2008).

Furthermore, even disregarding outside resources, a gradual replacement program may be established, as the amount of producers willing to adhere to new production rules may be initially low. We must highlight that as a management strategy for a gradual replacement program, negotiations should be started with producers with the lowest annual net profit, that is, cattle breeders, and later with eucalyptus, sugarcane and orange producers. Income sources as poultry, pig and fish farming, horticultural production and landscape were not taken into account for this research. These income sources would raise the watershed annual net profit and are therefore need of complementary studies. The deduction of permanent preservation and legal reserve areas established by the Forest Code in force should also be considered in more detail for further studies, as these areas should not be considered as productive.

In summary, analysis of the opportunity cost of the economic activities analyzed is a strategic tool to be used in decision-making processes aimed at proposing alternative production systems for the watershed. However, this tool should not be regarded only as a method of encouraging environmental preservation by means of financial compensation. Non-economic factors involving other values such as cultural, altruistic and landscape should be carefully considered.

\section{Acknowledgements}

The authors wish to thank the Coordination for the Improvement of Higher Education (CAPES) for their financial support and the São Paulo Research Foundation (FAPESP) for financing Process $n^{\circ}$ 98/10924-3 in connection with the International Institute of Ecology in São Carlos and the Federal University of Itajubá - UNIFEI.

\section{References}

ADAMS, V.M., PRESSEY, R.L. and NAIDOO, R., 2010. Opportunity costs: who really pays for conservation? Biological Conservation, vol. 143, no. 2, pp. 439-448. http://dx.doi. org/10.1016/j.biocon.2009.11.011.

ANUÁRIO DAAGRICULTURA BRASILEIRA-AGRIANUAL, 2008. Agrianual 2008: anuário da agricultura brasileira. 13rd ed. São Paulo: FNP Consultoria \& Comércio. 520 p.

ANUÁRIO DA PECUÁRIA BRASILEIRA-ANUALPEC, 2010. Anualpec 2010: anuário da pecuária brasileira. São Paulo: FNP Consultoria \& Comércio. $360 \mathrm{p}$.

BLANK, L. and TARQUIN, A., 2008. Engenharia econômica. 6th ed. São Paulo: Mcgraw Hill. 756 p.

BRASIL, Ministério da Fazenda, Secretaria da Receita Federal, 1996. Instrução Normativa SRF no 87, de 31 de dezembro de 1996. Aprova modelo de declaração, a ser prestada pelas entidades civis, de responsabilidade na aplicação integral dos recursos, recebidos mediante doação nos termos do art. $13, \xi 2^{\circ}$, inciso
III, da Lei $n^{\circ}$ 9.249, de 26 de dezembro de 1995. Diário Oficial da República Federativa do Brasil, Brasília, 3 jan. 1997, pp. 158.

BRASIL. Ministério da Agricultura, Pecuária e Abastecimento, 2009. Plano agrícola e pecuário 2010-2011. Brasília: Mapa/ SPA. 46 p.

CENTRO DE ESTUDOS AVANÇADOS EM ECONOMIA APLICADA - CEPEA, 2014. PIB do agronegócio - dados de 1994 a 2013. Piracicaba: ESALQ/USP.

COMPANHIA BRASILEIRADEABASTECIMENTO - CONAB, 2014. Balança comercial brasileira e balança comercial do agronegócio: 1989 a 2013. Brasília: MAPA/SRI/DPI/CGOE.

COSTA, C.W., DUPAS, F.A. and PONS, N.A.D., 2012. Regulamentos de uso do solo e impactos ambientais: avaliação crítica do plano diretor participativo do município de São Carlos, SP. Geociências, vol. 31, no. 2, pp. 143-157.

COSTA, C.W., DUPAS, F.A., CESPEDES, J.G. and SILVA, L.F., 2013. Monitoramento da expansão urbana, cenários futuros de crescimento populacional e o consumo de recursos hídricos no município de São Carlos, SP. Geociências, vol. 32, pp. 63-80.

CUNHA, R.C., 2012. Zoneamento ambiental em bacia hidrográfica utilizada como manancial urbano. Estudo do caso da bacia hidrográfica do Ribeirão do Feijão - São Carlos, SP. Itajubá: Universidade Federal de Itajubá,.127 p. Dissertação de Mestrado em Engenharia de Energia.

CUNHA, R.C., DUPAS, F.A., PONS, N.A.D. and TUNDISI, J.G., 2011. Análise da influência das variáveis ambientais utilizando inferência fuzzy e zoneamento das vulnerabilidades: estudo de caso da bacia hidrográfica do Ribeirão do Feijão, São Carlos, SP. Geociencias, vol. 30, no. 3, pp. 399-414.

DOSSA, D., CONTO, A.J., RODIGHERI, H. and HOEFLICH, V.A., 2000. Aplicativo com análise de rentabilidade para sistemas de produção deflorestas cultivadas e de grãos. Colombo: Embrapa Florestas. $56 \mathrm{p}$.

DUPAS, F.A., 2001. Crescimento urbano e suas implicações ambientais: redirecionamento de cidades de médio porte utilizando as variáveis ambientais, sensoriamento remoto e SIG - Estudo do caso de São Carlos, SP. São Carlos: Universidade Federal de São Carlos. 61 p. Final report of research postdoctoral, FAPESP.

DUPAS, F.A., SILVA-SOUZA, A.T., TUNDISI, J.G., TUNDISI, T.M. and ROHM, S.A., 2006. Indicadores ambientais para planejamento e gestão de bacias hidrográficas. In: J. G. TUNDISI, T. MATSUMURA-TUNDISI and C.S. GALLI, orgs. Eutrofização na América do Sul: causas, consequências e tecnologias para gerenciamento e controle - EUTROSUL. São Carlos: DMD, p. 491-506.

ERNST, C., 2004. Protecting the source: land conservation and the future of America's drinking water. Washington: Trust for Public Land and American Water Works Association. 56 p.

FEDERAÇÃO DAAGRICULTURA E PECUÁRIA DO ESTADO DE GOIÁS - FAEG, 2011. Estimativa de custo de produção da cultura de cana-de-açúcar. Goiânia: FAEG/GETEC.

FRÉLICHOVÁ, J., VAČKÁŘ, D., PÁRTL, A., LOUČKOVÁ, B., HARMÁČKOVÁ, Z.V. and LORENCOVÁ, E., 2014. Integrated assessment of ecosystem services in the Czech Republic. Ecosystem Services, vol. 8, pp. 110-117. http://dx.doi. org/10.1016/j.ecoser.2014.03.001.

GALINDO-LEAL, C. and CÂMARA, I.G., editors, 2003. The Atlantic forest of South America: biodiversity status, threats, and 
outlook. Washington: Island Press. 488 p. Center for Applied Biodiversity Science at Conservation International State of the Hotspots Series.

GALO, M., 2008. Eucalipto: custos de produção. Centro de Inteligência em Florestas - CI Florestas.

GHILARDI, A.A.; MAIA, M.L. and NEGRI, J.D., 2004 L Laranja para indústria: custo básico de produção na safra agrícola 2003/04. São Paulo: Instituto de Economia Agrícola/Secretária de Agricultura e Abastecimento.

HUPFFER, H.M.; WEYERMULLER, A.R. and WACLAWOVSKY, W.G., 2011. Uma análise sistêmica do princípio do protetorrecebedor na institucionalização de programas de compensação por serviços ambientais. Ambiente \& Sociedade, vol. 14, no. 1, pp. $95-114$

INSTITUTO BRASILEIRO DE ECONOMIA - IBRE. FUNDAÇÃO GETÚLIO VARGAS - FGV, 2011. Conjuntura estatistica. Revista Conjuntura Econômica, vol. 65, no. 2.

INSTITUTO BRASILEIRO DE GEOGRAFIA E ESTATÍSTICA - IBGE, 2007. Censo agropecuário 2006: Brasil, grandes regiões e unidades da federação. Rio de Janeiro: IBGE. 777 p.

INSTITUTO BRASILEIRO DE GEOGRAFIA E ESTATÍSTICA - IBGE, 2014 [viewed 15 February 2014].IBGE cidades@: São Carlos, SP [online]. Available from: http://cod.ibge.gov.br/233PR

INSTITUTO DE ECONOMIAAGRÍCOLA-IEA, 2010 [viewed 07 February 2010]. Preços médios mensais recebidos pelos agricultores [online]. Available from: http://www.iea.sp.gov.br/ out/bancodedados.html

MACHADO, F.H. and DUPAS, F.A., 2013. Análise econômica do uso do solo e da disposição a pagar para proteção ambiental dos recursos hídricos da bacia hidrográfica do manancial do Ribeirão do Feijão, São Carlos - SP. Geousp, vol. 33, pp. 111-126.

MACHADO, F.H., SILVA, L.F., DUPAS, F.A., MATTEDI, A.P. and VERGARA, F.E., 2014. Economic assessment of urban watersheds: developing mechanisms for environmental protection of the Feijão river, São Carlos - SP, Brazil. Brazilian Journal of Biology $=$ Revista Brasileira de Biologia, vol. 74, no. 3, pp. 677684. http://dx.doi.org/10.1590/bjb.2014.0073. PMid:25296217.

MARTINELLI, L.A. and FILOSO, S., 2009. Balance between food production, biodiversity and ecosystem services in Brazil: a challenge and an opportunity. Biota Neotropica, vol. 9, no. 4, pp. 21-25. http://dx.doi.org/10.1590/S1676-06032009000400001.

MARTINELLI, L.A., NAYLOR, R., VITOUSEK, P.M. and MOUTINHO, P., 2010. Agriculture in Brazil: impacts, costs, and oportunidades for a sustainable future. Current Opinion in Environmental Sustainability, vol. 2, no. 5-6, pp. 431-438. http:// dx.doi.org/10.1016/j.cosust.2010.09.008.

NEVES, F.R., 2005. Análise da influência de indicadores econômicos na escolha da estratégia de produção. Campinas: Universidade Estadual de Campinas, 129 p. Dissertação de Mestrado em Ciências e Engenharia do Petróleo.

PERIOTTO, N.A. and TUNDISI, J.G., 2013. Ecosystem Services of UHE Carlos Botelho (Lobo/Broa): a new approach for management and planning of dams multiple-uses. Brazilian Journal of Biology $=$ Revista Brasileira de Biologia, vol. 73, no. 3, pp. 471-482. http:// dx.doi.org/10.1590/S1519-69842013000300003. PMid:24212686.

POSTEL, S.L. and THOMPSON, B.H., 2005. Watershed protection: capturing the benefits of nature's water supply services. Natural Resources Forum, vol. 29, pp. 98-108.
RODRÍGUEZ, M.P., 2001. Avaliação da qualidade da água da bacia do alto Jacaré-Guaçu/SP (Ribeirão do Feijão e Rio do Monjolinho) através de variáveis físicas, químicas e biológicas. São Carlos: Universidade de São Paulo, 175 p. Tese de Doutorado em Ciências da Engenharia Ambiental.

ROSS, S.A., WESTERFIELD, R.W. and JAFFE, J.F., 2002. Administração financeira: corporate finance. 2nd ed. São Paulo: Atlas. $776 \mathrm{p}$.

SECRETARIA DE PLANEJAMENTO E GESTÃO DO ESTADO DE SÃO PAULO - SEADE. FUNDAÇÃO SISTEMA ESTADUAL DE ANÁLISE DE DADOS - 2014 [viewed 20 February 2014]. Perfil municipal: São Carlos - SP [online]. Available from: http:// www.imp.seade.gov.br/frontend/\#/perfil

SERVIÇO AUTÔNOMO DE ÁGUA E ESGOTO DE SÃO CARLOS - SAAE, 1989. Plano diretor do sistema de abastecimento de água de São Carlos - SP. São Carlos: Serviços de Engenharia Consultiva Ltda-SEREC. vol. 1.

SERVIÇO AUTÔNOMO DE ÁGUA E ESGOTO DE SÃO CARLOS - SAAE, 1995. Projeto executivo da barragem da captação do Ribeirão do Feijão. São Carlos: SAAE.

SPERANDELLI, D., DUPAS, F.A. and DIAS PONS, N.A., 2013. Dynamics of urban sprawl, vacant land, and green spaces on the metropolitan fringe of São Paulo, Brazil. Journal of Urban Planning and Development, vol. 139, no. 4, pp. 274-279. http:// dx.doi.org/10.1061/(ASCE)UP.1943-5444.0000154.

TUNDISI, J.G. and MATSUMURA-TUNDISI, T., 2010. Impactos potenciais das alterações do Código Florestal nos recursos hídricos. Biota Neotropica, vol. 10, no. 4, pp. 67-76. http://dx.doi. org/10.1590/S1676-06032010000400010.

TUNDISI, J.G., TUNDISI, T.M., DUPAS, F.A., SILVA-SOUZA, A.T. and SHIBATTA, O.A., 2007. Uso atual e uso potencial do solo no município de São Carlos, SP - base do planejamento urbano e rural. São Paulo: NEPA/IRN/UNIFEI. 95 p. Relatório final de projeto FAPESP.

TUNDISI, J.G.; MATSUMURA-TUNDISI, T.; PARESCHI, D.C.; LUZIA, A.P.; VON HAELING, P.H. and FROLLINI, E.H., 2008. A bacia hidrográfica do Tietê/Jacaré: estudo de caso em pesquisa e gerenciamento. Estudos Avançados, vol. 22, no. 63, pp. 159-172.

WATANABE, M., ORTEGA, E., BERGIER, I. and SILVA, J.S.V., 2012. Nitrogen cycle and ecosystem services in the Brazilian La Plata Basin: anthropogenic influence and climate change. Brazilian Journal of Biology $=$ Revista Brasileira de Biologia, vol. 72, no. 3, (suppl.), pp. 691-708. http://dx.doi.org/10.1590/ S1519-69842012000400008. PMid:23011299.

WHATELY, Y.M. and HERCOWITZ, M., 2008. Serviços ambientais: conhecer, valorizar e cuidar: subsídios para a proteção dos mananciais de São Paulo. São Paulo: Instituto Socioambiental. 119 p.

WÜNSCHER, T., ENGEL, S. and WUNDER, S., 2008. Spatial targeting of payments for environmental services: a tool for boosting conservation benefits. Ecological Economics, vol. 65, no. 4, pp. 822-833. http://dx.doi.org/10.1016/j.ecolecon.2007.11.014.

ZUQUETTE, L.V., PALMA, J.B. and PEJON, O.J., 2009. Methodology to assess groundwater pollution conditions (current and pre disposition) in the São Carlos and Ribeirão Preto regions, Brazil. Bulletin of Engineering Geology and the Environment, vol. 68 , no. 1 , pp. 117-136. http://dx.doi.org/10.1007/s10064008-0173-y. 